\title{
Organisational Supplying Behaviour: understanding supplier needs, wants and preferences
}

\begin{abstract}
The overall objective of this research is to improve the P\&SM field's understanding of the behaviour of suppliers with a longer term view to improving the ability of all buyers to influence the behaviour of suppliers in ways that match the buyers' requirements and preferences. The research identifies forty-nine elements in buyers' purchase offerings, behaviours and characteristics that suppliers regard as important. These have been conceptualised as Sources of Supplier Value (SOSV). This paper seeks to establish a common vocabulary for describing supplier needs, wants and preferences and their impact on buyer attractiveness. In view of the current paucity of research and understanding in this subject area, the paper's main contribution is a coherent theoretical framework, terminology and rationale for investigations into the phenomenon of Organisational Supplying Behaviour.
\end{abstract}

Paper type: Notes and Debates

Keywords: Supplier Value; Buyer Attractiveness; Organisational Supplying Behaviour 


\section{Organisational Supplying Behaviour: understanding supplier needs and wants}

\section{INTRODUCTION}

There have been a number of references in recent years to efforts by companies to obtain a better response from suppliers by increasing their attractiveness as buyers and becoming 'customers of choice': see for example Kanter (2008); Ellinor (2008), (2007); Cordon \& Vollman (2005); Ellegaard et al, (2003); Christiansen \& Maltz, (2002) - see also Ellegaard \& Ritter (2006a) for a detailed discussion of the meaning of the word 'attractiveness' in this context. One objective of this paper is to take that idea from the very large company sector where it currently, mainly resides, and extend its application to any size or kind of buyer. Consider the experience of a very small company trying to buy supplies from a very large supplier that no longer considers the buyer worth trading with. The traditional tools employed by large company buyers to persuade suppliers to do their bidding - significant orders, threats to withdraw business, competitive pressure and the like are not available. Moreover, the suggested 'best practices' recommended as means of increasing attractiveness by Cordon \&Vollman (2005) for example, such as avoiding 'hard-hitting negotiation', making sure that the supplier knows that their 'ideas are welcome' encouraging the supplier to 'learn from the buyer' and so on are totally inappropriate. There is no prospect of the small buyer ever becoming a 'customer of choice', and if they wish to change the supplier's behaviour they will have to find other means of attracting their attention. They will need to understand what that supplier needs and wants, and hope that, in the absence of large orders or the other seductive attributes of very large customers, they can discover something that will satisfy some of those requirements. Note that the small company example above is an extreme. The benefits of an enhanced understanding of supplier needs, wants and preferences will not be confined to small or weak companies. Large powerful buyers, for example, experiencing 
difficulties in strategic supplier partnerships will be able to draw usefully upon the same resource to improve their troubled trading relations. Indeed, buyers of all types regularly find themselves having difficulty persuading suppliers to do what they want, and may be able to benefit from the ideas below. Thus the primary purpose of this paper is to explore the needs, wants and preferences of suppliers with a view to informing all buyers' understanding of their suppliers' wishes and behaviour. It will be argued that buyers may be able to use an enhanced understanding of supplier preferences to influence their behaviour in a beneficial manner. In pursuit of that objective, the paper proceeds to formally define the concepts of 'Supplier Value' and 'Sources of Supplier Value'; explore and critically assess published descriptions of buyer characteristics that suppliers find attractive; present the findings of a pilot study of Small and Medium-Sized Enterprise (SME) attitudes towards such characteristics; identify areas for future research; outline an application of knowledge of Sources of Supplier Value for buyers seeking to influence supplier behaviour and finally locate the whole subject within a proposed new sub-field of Purchasing \& Supply Management (P\&SM hereafter).

\section{SUPPLIER DECISION-MAKING}

During trade, buyers assess the bundle of potential costs and benefits represented by a supplier's sales offerings, and either place orders, negotiate a better deal, or seek alternative sources.

Marketing contains the sub-fields of 'Consumer Behaviour' devoted to understanding the decisionmaking processes of amateur buyers, and 'Organisational Buying Behaviour' (OBB hereafter) focussing on the behaviour of professionals: see Tanner (1990); Sheth (1996); Wilson (1996); Webster \& Wind (1996); Ellis et al (2002). There has also been a considerable amount of research carried out by IMP-affiliated researchers into interactions between buyers and suppliers - see for example Ulaga \& Eggert (2005) and their discussion of 'relationship value'. The overwhelming 
majority of that particular body of work shares the wider Marketing field's focus on the interests of organisations-as-suppliers and the behaviour of customers - see Ulaga \& Eggert (2006) for a clear illustration of this observation. As a result the supplier-selection decision-making processes of buyers are relatively well researched and understood: for a view of those processes from the P\&SM literature see De Boer et al (2001). In contrast the decision-making processes of suppliers are largely unexplored. Although there is a limited amount of published work throwing light on the nature of the needs, wants and preferences that influence suppliers' behaviour, there is, as yet, no organised research effort equivalent to OBB in the P\&SM field dedicated to exploring the subject. Indeed some of the existing insights are incidental by-products of research into a variety of other, unrelated topics. Consequently the equivalent decision-making processes during which suppliers decide whether or not to supply any given customer or potential customer - 'customer selection' hereafter, - and how responsive to be to requests for action from any selected customer - the degree of 'supplier responsiveness' hereafter - remain comparatively poorly explored: see Venkatesan \& Kumar (2004); Yorke \& Wallace (1986) on the subject of customer selection and Carr \& Smeltzer (2000); Holweg (2005) for discussion of supplier responsiveness. The phrase 'customer selection' may stimulate connections in some readers' minds with the Marketing concepts of 'market segmentation' or 'targetting'. However the processes of market segmentation and targetting are unambiguously buyer-centric, by which we mean they are primarily focused on increasing sales by identifying different buyer needs and trying to satisfy them. Here, for example, from a standard Marketing text, the process of market segmentation is described as a process in which marketers:

...identify and profile distinct groups of buyers who differ in their needs and preferences.

Kotler, 2003, p. 279 
In contrast, both customer selection and indeed this entire paper are unambiguously suppliercentric. Thus customer selection has nothing to do with Marketing's concern for identifying buyers' needs and behaviours, and everything to do with the need for Purchasing to identify suppliers' wants, needs and preferences. In order to better understand these processes it is necessary to know which behaviours and characteristics suppliers find attractive in a buyer.

\section{INITIAL CONCEPTS: SUPPLIER VALUE AND BUYER ATTRACTIVENESS}

The net benefit that customers obtain from any given exchange in trade with suppliers, less the costs of that exchange, has been extensively studied in the Marketing field under the title of 'value' or 'customer value' - see Lindgreen \& Wynstra (2005) for a recent review. Blois (2004) offers an admirably clear definition of the concept thus:

...the value $\left(\mathrm{Vc}_{\mathrm{c}}\right)$ that a customer perceives it will gain by making a purchase from a particular supplier... [is represented by] the difference between the perceived benefits (Bc) and the perceived life time costs (LCc) arising from making the purchase. That is: $\mathrm{Bc}-\mathrm{LCc}$ $=\mathrm{Vc}$

The concept of customer value underlies much of our current understanding of buyer decisionmaking processes, and particularly those connected with supplier-selection. To improve our understanding of supplier decision-making processes the analysis below refers to the mirror-image of Marketing’s 'customer value', namely: 'supplier value' as experienced by suppliers: see Ramsay (2005)for a more detailed exploration of the concept of supplier value. By modifying Blois’ treatment above, a formal definition of Supplier Value can be derived thus: The supplier value (Vs) 
that an organisation perceives it will gain by supplying a particular customer is the difference between the perceived benefits $(B S)$ and the perceived life time costs $(L C S)$ arising from supplying that customer. That is $V s=\left(B_{S}-L C S\right)$. Supplier value thus represents the net benefit suppliers receive from the act of trading with a given customer. To repeat, this paper is not about Customer Value and the supplier characteristics that buyers find attractive, it is instead an exploration of Supplier Value; a phenomenon that derives from those attributes of buyers or customers that suppliers perceive as attractive. In a discussion of the idea of buyer 'attractiveness' Ellegaard et al (2003) describe the difficulties of empirically measuring that particular characteristic. Although the concept of supplier value may not directly help in the collection of data on attractiveness, it may be used to explain the basis of buyer attractiveness and thus, in the longer term, assist research in this area. When suppliers are presented with purchase offerings from buyers in the form of, for example, purchase enquiries, they may be thought of as performing a calculation of the potential net benefit, or supplier value Vs it represents (see Figure 1). If they consider the magnitude of Vs to be sufficient, they may select the customer and accept the order. The degree of responsiveness to buyer requests made thereafter may also be affected by the expected magnitude of Vs. It is proposed therefore that, ceteris paribus, the greater the amount of $V_{s}$ a buyer offers to a supplier, the more attractive that buyer will appear and hence the more likely that supplier will be to either, choose them as a customer, or after trade has begun, respond favourably to buyer requests for supplier behaviour modification. If the various sources from which Vs derives can be identified, the task of measuring attractiveness may be eased, and as we shall see, buyers may be offered a method of dealing with uncooperative or uninterested suppliers or, more generally, increasing their influence over any supplier's behaviour.

\section{SOURCES OF SUPPLIER VALUE}


Purchase offerings in the form of purchase enquiries and orders embody a variety of elements of the proposed purchase, each of which represents potential costs and benefits for the supplier. Thus they will normally include relatively tangible elements such as a quantity of the product or service. Whilst promising increased revenue, this element may also, for example, represent production difficulties and on-costs for the supplier. The offering will usually include the purchase's technical specification, and this might involve either cost-reducing or increasing modifications to the supplier's processes. The list of elements will also include quantities of money in the form of price and quantity offers; proposed payment timings and so on. In ongoing trading relationships it will also represent much less tangible elements such as the prospect for the supplier's staff of further personal interactions with the buyer's purchasing staff, possible difficulties with the buyer's goods handling or invoice processing personnel and so on. Suppliers assess the bundle of potential costs and benefits represented by the buyer's purchase offering, and decide whether to respond with a sales offering, possibly in the form of a quotation/order acknowledgement that matches the offering and embodies a bundle of costs and benefits for the buyer, or to make counter proposals, or perhaps to decline the enquiry/order entirely. Thus Vs is derived from a mixture of buyer characteristics, behaviours and purchase attributes each of which has an effect on the supplier's economic wellbeing and efficiency of operation. These disparate elements we have named 'Sources of Supplier Value' (SOSVs hereafter) and the content analysis of a number of key papers follows.

\section{LITERATURE ANALYSIS}

In conducting the following analysis the Ebsco Business Source Premier database and Google Scholar were searched using a variety of phrases such as 'supplier value', 'customer attractiveness', 'customer selection' and 'customer attributes'. The overall lack of awareness and attention currently paid in the P\&SM field to the concept of supplier value in particular, and supplier needs, wants and 
preferences in general, is vividly illustrated by the fact that the main, standard texts in the P\&SM field make no mention of the phenomena. Thus Van Weele (2005); Bailey et al (2005); Christopher (2005); Monczka et al (2005); Chopra \& Meindl (2007); and Benton (2007) all discuss what suppliers can offer buyers and how supplier performance and behaviour is likely to affect buyers, but no make no reference to the mirror-image processes. Nevertheless, there is a limited number of papers, mainly in the P\&SM literature that deal directly with supplier needs, wants and preferences, and a variety of papers in the Marketing literature that deal with the subject in an indirect manner (illustrated by example below). Consequently, what follows is not so much a conventional literature review as the outcome of a search of those literatures in pursuit of relevant ideas. The publications below have been divided into direct and indirect treatments of the subject matter and considered in the order in which they were published. One aim of this paper is to generate an extensive index of possible SOSVs, but many of the same ideas are referred to in different contexts and by more than one author. For example, Ramsay (2005); Maunu (2003), Rozemeijer \& Van Weele (2002) and Russill (1997) all suggest, in a variety of different ways and contexts, that suppliers may prefer buyers who offer them stable order patterns. Consequently to avoid excessive repetition of citations in what follows, only the earliest found reference to each SOSV will be cited in the text, although a complete listing of SOSVs and the various authors that refer to each of them can be found in Table 1 below. It should also be noted that no claim is being made to generate a definitive, comprehensive list of all possible SOSVs and their literary origins. Many authors other than those referred to below will have mentioned the various buyer characteristics identified here as SOSVs, however nothing would be gained by attempting to list all such references. The aim is to create an extensive list of different SOSVs rather than an exhaustive list of those who have referred to relevant characteristics. 


\section{Direct references}

[NB the words in bold in what follows are the titles given to the various SOSVs listed in Table 1 below]. The fact that, with the honourable exception of non-profit organisations, suppliers require profit has been so frequently referred to that it would be absurd to single out any individual literary source (Overall Profit). The importance of the attractiveness to suppliers of the money the buyer has to offer was discussed in the context of a discussion of power and dependence in Ramsay (1994). That paper refers specifically to the volume of money (Sales Volume), the ratio of the buyer's expenditure with a supplier to the supplier's total sales revenue (Sales Impact) and also to the form of money on offer - cash, credit terms, currency and so on (Payment Format). The Sales Impact idea appears in the Marketing field in later years in the key account literature (Mack 1971; Anderson 1984). In general terms, suppliers prefer more money to less; are more likely to be responsive to buyers whose expenditure constitutes a greater rather than a smaller proportion of their total sales, and are likely to prefer more over less liquid forms of money. The same paper also discusses the role played by dependence in affecting the relative power of buyers and suppliers. The relationship that suppliers and buyers have towards power is extremely complex, however, in general suppliers will tend to prefer, where possible, to retain their own independence while trading with dependent buyers (Supplier Independence/Power: Buyer Dependence/Power). Dependence and power are also affected by a host of factors too numerous to include here. Suffice it to say that both concepts may be discussed indirectly, for example, in terms of the number of competitors vying for a given customer's business (Fiocca, 1982). Power and dependence may also be thought of as opposite sides of the same coin. Supplier independence and buyer dependence might be regarded in a similar light, and thus not worthy of separate treatment. However, we would suggest that whilst some suppliers might be concerned to retain their freedom of action and avoid becoming dependent upon any given buyer, others might be actively interested in trading with 
dependent buyers. In the process of describing a variety of methods of measuring buyer power Ramsay (1996) goes into some detail on the effects of different measures of types of sales revenue on buyer attractiveness (Revenue Elements - of Overall Profit). Russil (1997) observed that customers who regularly seek alternative sources of supply will be less attractive, and that customers who possess good planning systems or demand low levels of specification change and thus offer stable demand facilitating effective supplier planning processes and minimising the risk of obsolescence, will be preferred to customers displaying the opposite characteristics (Demand Stability). Suppliers will also tend to prefer customers who pay their bills on time (Financial Probity), and some customers may possess favourable public or market reputations - e.g. Rolls Royce - that make them appear attractive to suppliers regardless of the relative profitability of the resulting exchanges (Reputation). This last SOSV has also been referred to indirectly in the form of the importance to suppliers of the customer's market share in its own sales markets (Fiocca, 1982). Russil (1997) also stressed the fact that sales and marketing staff tend to favour interactions with individuals that they like in the buyer's organisation. A variety of factors will come into play here such as prejudices concerning race, gender, religion or past experiences concerning individual staff (Personal Preferences). In the Marketing field, Walter et al (2001) described a number of what they called 'functions of business relationships' which in this context can be seen to be SOSVs. They point out that companies operating in highly unstable markets may seek a secure stream of relatively unprofitable sales as an insurance against unforeseen demand failures (Revenue Insurance). They may also like customers who can assist with product innovations and improve the supplier's efficiency or technological competence (Customer-led Innovation), or help them to establish relationships with new customers in new markets (Market Access), or provide other information about their sales markets (Market Information). Finally they may prefer customers capable of facilitating their access to other organisations such as banks 
(Institutional Access). Back in the P\&SM field Christiansen \& Maltz (2002) describe how some buyers are able to offer suppliers the opportunity to test and develop new technologies, while others train the supplier's staff (Supplier-led Innovation Support). The companies they investigated argued that some suppliers dealing with technical products appreciate working with appropriately trained purchasing personnel (Appropriately Trained Staff) and prefer longer-term relationships or contracts (Long-term Interactions). This last SOSV is discussed indirectly by some authors in terms of brand or supplier loyalty: e.g. Campbell \& Cunningham (1983).

Customers who agree to share the risks represented by, for example, the development of innovative new products may be perceived as attractive (Risk sharing). Christiansen \& Maltz (2002) also suggest that suppliers may favour customers who show an explicit concern for the supplier's interests by, for example, offering firm, long-term future order cover over those only prepared to make shorter-term commitments (Customer Attentiveness). Rozemeijer \& Van Weele (2002) argue that companies whose planning systems produce reliable forecasts of future demands and changes will be preferred (Forecast Reliability), and that suppliers, particularly in fast changing, technologically complex product sectors, may regard early involvement in the customers' R\&D processes as essential for securing future orders (Early R\&D Involvement). They also point out that suppliers like to know precisely who in the customer organisation they have to deal with; who has responsibility for different activities, the precise nature of the organisation structure and so on (Clarity of Roles and Responsibilities), and that some suppliers prefer face-to-face meetings as a form of communication (Personal Meetings). They found that suppliers may like to receive information from their customers about their perceptions concerning the effectiveness of the supplier's operations (Performance Feedback), and finally that large strategically critical suppliers dealing with large buying organisations may like joint team working as a form of communication (Joint Teams). Cordon \& Vollmann (2002) concentrate on the opportunities that a 
buyer can offer to suppliers to learn from the buyer's operations (Supplier Learning

Opportunities). Maunu (2003) reports that sales and marketing staff prefer trustworthiness in their buying counterparts as this may be associated with a reduction in both risk and duplication of effort (Trustworthiness). Ramsay (2005) observes that customers who are unusually generous, wealthy, or incompetent - in the sense of offering high prices or unusually favourable payment terms, for example, may appear attractive (Windfalls). At the individual level, all staff are motivated, inter alia, by salary, security, status, power, prestige, professional excellence and respect. Consequently suppliers will prefer deals with customers that result in improvements to those aspects of their lives (Personal Motivation). Cordon \& Vollmann (2005) observe that operational/technical staff in suppliers regard all changes as problematic (Low Modification Rate), and like to deal with the same people over time (Contact Stability). They suggest that suppliers prefer customers who treat them fairly (Fairness) and do not like customers who habitually apply heavy negotiating pressure (Lack of Negotiating Pressure) and prefer those who are open and receptive to supplier ideas and suggestions (Receptiveness to Supplier Ideas).

\section{Indirect references}

Some of the main Marketing texts make no explicit mention of supplier preferences, motivation, wants, and needs or the concept of supplier value - see for example Webster (1991); Brassington \& Pettitt (2006), instead their focus is overwhelmingly on what customers want. However, although the discussion is not couched in terms of a direct reference to the concepts of supplier needs, wants and preferences there are many publications that mention the importance of overall profitability. This is frequently presented in the form of a discussion of 'customer lifetime value' - see for example Kotler (2003); Baker (2000); Hollensen (2003). There are indeed quite a large number of specialised papers dealing exclusively with this single SOSV - for example Roemer (2006); 
Venkatesan \& Kumar (2004); Reinartz \& Kumar (2003). The same narrow emphasis can be found in the Industrial Marketing sub-field - see for example Dwyer \& Tanner (1999). Wider insights may be garnered from the small number of works dealing with customer or account portfolio analysis. These publications are intended to guide suppliers in the process of customer selection, and do not directly address the question of supplier needs, wants and preferences. Instead, suppliers are offered a variety of factors to consider when categorising and distinguishing between their customers. Thus Fiocca (1982) discussed the importance to suppliers of customers who can help in the process of sales/product diversification (Diversification Facilitation) or improve relationships with other customers (Competitor Sales Support). The same paper discusses the idea of the attraction of potential future sales (Sales Potential) along with reference to the idea of the cost of serving different customers and with details of various customer and product characteristics that may generate additional costs and thus reduce profitability (Cost Elements - of overall profit). The indirect nature in which many of these portfolio treatments deal with the subject of supplier needs, wants and preferences is clearly illustrated in Campbell \& Cunningham (1983) in which suppliers are recommended to split customers up into classes on the basis of five factors: Sales Volume, 'Use of Strategic Resources' (this may be viewed as a measure of Sales Potential), 'Age of Relationship', 'Supplier's share of Customer's Purchases' (this may be viewed as a measure of buyer dependency), and 'Profitability of Customer to Supplier'. Using these factors the authors divide customers into categories such as 'Tomorrow's Customers' who exhibit low sales volume, high use of strategic resources, a new relationship a low share of customer's purchases low profitability, leading to this description:

These are the customers that the company is trying to gain, or regain, at home or abroad. They may be customers in a new market area, opened up as a result of technical developments, they may be vital 'reference point' customers in an export market. Sales to 
these customers are low, but strategic resources are allocated to improve the current sales position and develop the relationship.

Campbell \& Cunningham, 1983, p. 372

The authors go on to discuss the role played by the growth rate of sales to any given buyer as well as the levels of supplier and buyer dependence. All of the factors described in this analysis have already been dealt with above, with the exception of growth rate of sales and the age of the trading relationship. The former can be regarded as a measure of sales potential. In Campbell \& Cunningham's analysis, old relationships are much less desirable than new ones, and age appears to be an overall, negative constraining factor on levels of $\mathrm{V}_{\mathrm{s}}$. However, since long relationships may not only lead to 'closer', more mutually beneficial interactions but also to 'closer', conflictladen interactions, what matters is not the length of the relationship but its quality. Thus the age of the relationship is not itself an SOSV. In the current context, the process of 'customer analysis' advocated by these various portfolio authors may be seen as an evaluation of bundles of small number of SOSVs. Shapiro et al (1987) focus on profitability and discuss both customer pricing behaviour and the 'cost to serve' by offering a breakdown of the cost elements of overall profit into pre-sale, production, distribution and post-sale service costs. Krapfel et al (1991) offer an approach incorporating the breaking down of dependence into four contributing factors: criticality, quantity, replaceability and slack that they argue make up a construct they call 'relationship value'. One may infer that relationships with buyers involving lower levels of supplier dependence will be regarded as more attractive. Alongside 'relationship value' Krapfel et al place 'interest commonality' a concept that they borrow from the conflict management literature in Psychology:

Interest commonality reflects an actor's economic goals and their perception of the trading partner's economic goals. When buyer and seller economic goals are compatible, interest 
commonality is high, and vice versa.

Krapfel et al, 1991, p. 26

The higher the interest commonality the more attractive, ceteris paribus, the buyer will appear. In the current context this SOSV may be regarded as an element in the supplier's perception of the risks associated with trading with any given buyer (Interest Commonality). Finally, Ford et al (2003), may be regarded as representing the body of work in the interaction literature. They echo many of the SOSVs detailed above such as the importance of profitability and sales impact, but also place a heavy emphasis on the importance of effective and harmonious personal, interorganisational staff relationships (Good Inter-organisational Staff Relationships). These, they argue, are essential, not merely to satisfy the personal preferences and motivations of the supplier's staff, but much more importantly to create the necessary environment for a variety of essential activities such as negotiations; the establishment of effective communications during crises; the development of levels of trust that make the exchange of confidential information possible and also beneficial feelings of personal obligation. The concept of customer portfolio analysis has also migrated into some more mainstream texts such as Hutt \& Speh (2007) and Ford et al (2003) in Industrial Marketing. To repeat, it is not suggested that every possible reference to information relevant to SOSVs has been collected in the analysis above. However it is argued that the overwhelming majority of useful direct references in the P\&SM field have been captured, along with a reasonable sample of the more relevant, mostly indirect, references from Marketing.

Due to space limitations, full descriptions of the SOSVs outlined above have been omitted from this paper, but readers interested in further details may follow the references shown in Table 1 below in which SOSVs have been organised within various categories on the basis of either the supplier processes upon which they tend to exert the most influence, or that have the most impact 
on the customer's perceived attractiveness to the supplier. For example, those sources whose influence on supplier perceptions of customer attractiveness were experienced in the communication process between trading organisations were allocated to the category 'Communication' and so on. The influence of some SOSVs is manifest in processes in more than one category. 'Financial probity' - by which is meant the likelihood that a customer will pay its bills reliably on time - could fall under both 'finance' and 'risk and uncertainty'. However, consider a supplier deciding whether or not to trade with two customers who offer the same potential volume of revenue, but one has a poor payment record. In such circumstances the customer with the suspect financial probity would appear less attractive to the supplier, and the primary influence of the payment record would be on the supplier's perceptions of the risks associated with trading with that customer. Hence the decision to allocate that particular SOSV to the category of 'Risk and uncertainty'. In such cases the choice of category was dictated by the feature of the SOSV that had the most impact on the customer's attractiveness to the supplier.

\section{$\underline{\text { Table } 1}$}

[take in Table 1]

\section{SHORTCOMINGS IN THE EXISTING TREATMENTS}

Although many of the existing published treatments were based upon empirical data collected from, or generated conclusions subsequently tested upon, companies, none focused on the most common form of company in every economy - small organisations with less than 50 employees. In the UK in 2006, $99.3 \%$ of all business enterprises had less than 50 employees and $73 \%$ of the total were sole proprietors with no employees at all: Department for Business Enterprise \& Regulatory 
Reform (2007). Thus Campbell \& Cunningham (1983) based their research on a 'leading' company in the packaging industry, Russil (1997) wrote from experience in large multinationals and Walter et al (2001) tested their ideas on large suppliers with an average of 445 employees per firm and very large customers averaging 1076 employees per firm (p. 369). Rozemeijer \& Van Weele (2002) were interested in strategic partnerships formed by large companies, Cordon \& Vollman (2002);(2005) worked with large multinationals and Christiansen \& Maltz (2002) also focused on extremely large companies. Maunu (2003) investigated one very large multinational and although Ellegaard et al (2003) argue that the case company upon which they base their findings is unlike the 'huge', 'powerful' companies such as Toyota that are used in so much of the work in the P\&SM field, their chosen company remains:

...the largest industrial company in Denmark.

Ellegaard et al 2003, p. 348

Furthermore although all of the papers may be regarded as referring to factors that suppliers find attractive in a customer, many sought the opinions of buyers rather than suppliers. It is possible that the large company, buyer-centric bias that characterises much of the literature in this subject area to date means that key sources of $\mathrm{V}_{\mathrm{s}}$ as perceived by the most common form of supplier - small ones may have been overlooked. Consequently a small empirical pilot study was designed with a view to determining whether SMEs share the same needs, wants and preferences as their much larger brethren.

\section{PILOT STUDY}

\section{The Objective}


In light of the above discussion a small pilot study using interviews was undertaken with a view to answering the following research questions:

What characteristics and behaviours do small and medium-sized suppliers want and need from their customers?

Do the characteristics and behaviours favoured by SMEs differ from those favoured by large organisations?

Face-to-face interviews were conducted with key account managers and Managing Directors in fourteen SMEs supplying UK supermarket buyers.

\section{Sample Selection}

SMEs were chosen who supplied food or drink products to leading UK multiple grocery retailers, and ranged in size from fifteen to one hundred employees (average 70). The organisations all supplied large supermarkets in the UK, and as government research in this market has revealed see Competition Commission (2000) - some of these are quick to use their power to punish what they regard as supplier misdemeanours. Therefore, despite promises of confidentiality, it was considered that some respondents might be deterred from speaking freely and frankly by the risk of incurring customer displeasure. This anxiety was realised when one company withdrew from the study entirely upon learning that even anonymised results might be published. Consequently, questions seeking data about supplier attitudes towards customer behaviour were employed that did not require the respondents to specify customer identities. To not only avoid the problem of influencing responses by offering respondents possible customer attributes that they might feel obliged to confirm as of interest, but also to avoid potentially limiting the range of possible responses by presenting the respondents with a priori constructs, no mention was made of the 
concept of SOSVs. Finally, entirely broad and open questions were employed to minimise the risks of influencing the respondents with the researchers' preconceptions. For example questions posed included: "Who is your best customer and why?"; "What aspects of your customers behaviour do you dislike and why?"; "Have you ever walked away from a customer and why?". Framing questions is such a manner enabled respondents to answer openly, without being subjected to possible preconceived ideas of the researcher

\section{Data Analysis}

An analysis of the fully transcribed interviews was undertaken in the light of the SOSVs extracted from the literature. In the first instance transcripts were read closely and analysed separately by two researchers, then the results compared in order to ensure consistency in interpretation.

\section{Findings}

The analysis showed that 25 of the responses offered by the suppliers matched the descriptions of the 42 SOSVs identified in the literature and shown in Table 1. Thus one respondent stated that:

The branded side is important because we are more in control of that. The danger with the own-label is they will test your nerve by putting out tender or threatening with price. But with our brands we are in control. (Supplier 6)

This was interpreted as a positive reference to the Supplier Independence/Power SOSV. Another stated that:

The biggest benefit we have had in developing our business is in the professional standards they set which hopefully results in us being professionally run. (Supplier 1) 
This was interpreted as a positive reference to the Customer-led innovation SOSV, and so on. Further examples of sample responses and the previously identified SOSVs to which they were allocated are shown in Table 2 below.

\section{[Take in table 2]}

Six of the suppliers' responses were sufficiently unlike the existing SOSVs to suggest that they deserved new titles of their own. For example, although the P\&SM literature discusses the relative attractiveness of different forms of payment and the importance of paying on time, one supplier stressed the importance of paying quickly, viz:

The favourite customer is the one that pays the quickest. (Customer 1) agreed 28 days, It was more and we said we were a small company and we need the money. It has worked well. (Supplier 9)

This was given the title: Speed of Payment. One supplier complained that:

...the difficulties have been payment and orders. Customer 2 is a paperless transaction - but they can't seem to process quickly. (Supplier 3)

The problems suppliers experience in dealing with the administrative requirements of large powerful customers is not something that the published research into large powerful buyers has picked up. Hence the addition of: Administrative Flexibility. Five respondents reported dissatisfaction with customers whose purchasing personnel were difficult to contact, for example:

It is hard to get hold of the buyer. I have been involved with the [title deleted] initiative with Customer 2 but this still needs to be approved by head office. (Supplier 3). 
This has been given the title: Staff Access. Within the category of 'Ethical Behaviour' one respondent stated baldly that:

They (the customer) have honesty in trading. It is our mission to be honest. (Supplier 14)

Thus: Honesty. Two companies referred in a disapproving a manner to corrupt buyer behaviour, for example:

(Customer 1) does not ask for cash bungs. They use standard trading deals...This is much more commercial and ethical. (Supplier 8)

This has been given the title: Absence of Corruption. One supplier referred to the undesirable effects of very unstable prices, thus for example:

We would only get rid of a customer if they made unreasonable demands on price such as daily negotiation. (Supplier 2)

This has been given the title: Price Stability.

Finally one supplier stated that:

(Customer 4) uses EPOS data to give an idea of the volumes through stores. But that is all the information that is given. The buyer then expects automatic replenishment. It is important to liaise with logistics people to ensure this happens. (Supplier 8)

This appears to refer partly to the category of Risk and Uncertainty, say, 'forecast reliability' and partly to Overall Trading Relations and Communication, say, 'customer attentiveness'. While it would be perfectly possible to record this kind of response against several of the existing SOSVs this would undermine one of the principal aims of this paper which is to improve buyer 
understanding of supplier needs wants and preferences. Thus brevity in the number of SOSVs generated is not a virtue. On the contrary, a long, varied list of SOSVs with rich details of the variety of supplier needs, wants and preferences is desirable. Accordingly, the fact that suppliers prefer buyers who provide necessary information in a timely manner was given the title: Free $\boldsymbol{\&}$ Timely Information Flow. The frequency with which each SOSV was identified by the various respondent companies is shown in Table 3 below with the 'new' sources uncovered in the current study highlighted in bold.

\section{[take in Table 3]}

\section{Discussion}

It is tempting to regard the frequencies in Table 3 as a generalisable ranking of SOSV preferences in SMEs. However, the limited size of the sample and its concentration in one kind of market clearly prevent any such conclusion. What can be stated with certainty is that 32 different SOSVs were referred to by the respondents in the pilot study, and of those, 22 were referred to by three or fewer suppliers. Moreover, no two companies chose to mention the same bundle of SOSVs. It would thus appear that similar suppliers all trading with a small number of frequently shared customers can have widely differing perceptions or preferences with respect to buyer characteristics and behaviours. Although the range of SOSVs referred to might have been expected if the research had focused on disparate suppliers dealing with disparate customers in a variety of markets, it is perhaps surprising and intriguing in a study examining a small group of similarly sized companies dealing with a small number of common customers. If this finding was replicated in other markets and with larger samples of suppliers, it would have profound implications for buyers seeking to determine how best to modify their purchase offerings in order to attract or influence recalcitrant suppliers. It might prove impossible to draw up generally applicable rankings 
of SOSVs to guide such decision-making, and buyers may need to seek individual rankings of preferences from individual suppliers. However, despite the variety of SOSV preferences on display, the results indicate that small companies share many of the same needs, wants and preferences as their larger brethren (25 out of a total of the 42 literature-based SOSVs were referred to). If we consider the SOSVs that were referred to by at least five of the respondents, the results also show that in this particular market, where a small number of very large buyers dominate trade, the small suppliers approached in the study shared particular concerns about the failure of the buyers to offer them adequate profits, attention, timely information, access to staff and independence. It is not possible to know from this pilot whether these common concerns are the result of the fact that in the market in question some of the buyers have a reputation for being unethical, domineering, cost-cutting commercial bullies, or merely reflect the 'normal' preferences of any supplier dealing with much more powerful customers. The desirability of further research into the distribution of SOSV preferences in different markets with differing kinds of organisation would thus appear warranted.

\section{FUTURE RESEARCH}

There are two areas of research arising immediately from the current discussion, the first concerns the proposed theory about supplier behaviour and the second about the difference between the behavior of SMEs and large companies. The theory concerns the suggested link between the amount of Supplier Value that a buyer offers to a supplier and the effect of that offering on the suppliers' behaviour. From this come two possible hypotheses:

$\mathrm{H} 1$ : the greater the $\mathrm{V}_{\mathrm{s}}$ offered by a buyer, the more likely any given supplier is to select or retain that buyer as a customer. 
$\mathrm{H} 2$ : the greater the $\mathrm{V}_{\mathrm{s}}$ offered by a buyer, the quicker, more enthusiastic and complete will be the response of any given supplier to requests from that buyer for modifications to the supplier's behaviour.

The findings of the SME pilot study indicate that it is not safe to generalise across different types of companies. Consequently it would be extremely useful to conduct a large-scale survey to test the following hypothesis:

H3: The distribution of SOSV preferences displayed by suppliers varies with respect to: customer type; product type; relative size of supplier and customer; industry.

\section{CONCLUSIONS}

The search of relevant literatures for references to supplier needs, wants and preferences revealed a number of publications in different fields employing a range of approaches and terminologies. All of the empirical work was heavily skewed towards the interests and problems of very large companies. The publications have no shared vocabulary to facilitate wider communication of the relevant concepts, and they lack a clear articulation of the underlying constructs. A small pilot study was conducted to explore the applicability of the existing work to SMEs. The findings indicated that SME preferences were far from homogenous and uncovered SOSVs missing from the extant large company research. It is hoped that this paper rectifies some of the current shortcomings in the subject area by:

a. Formally defining the concept of Supplier Value and arguing that it can be used as the basis of a common terminology for discussing the customer selection and responsiveness decision-making processes of suppliers. 
b. Introducing the concept of Sources of Supplier Value, generating an initial listing of examples of the phenomenon, and demonstrating its relevance for buyers seeking to influence supplier behaviour.

In much the same way as research based on the concept of Customer Value has improved understanding of buyer behaviour in the Marketing field, so work based on the concept of Supplier Value in the P\&SM field may reasonably be expected to improve our understanding of supplier behaviour. When the 'future research' proposals above have been completed, one might assume that this new topic will be exhausted. However, the generation of a more comprehensive list of SOSVs and some insight into how supplier preferences vary will constitute the beginning rather than the end of the process. Reference was made in the introduction to this paper of the sub-field of Marketing called Organisational Buying Behaviour which in its applied form seeks to improve the performance of organisations-as-suppliers rather than buyers, by focusing on trying to understand customer decision-making processes. One `can conceive of a mirror-image, supplier-focused analogue to OBB that may be called 'Organisational Supplying Behaviour' (OSB hereafter) that would comprise a sub-field of P\&SM dedicated to understanding the decision-making behaviour of suppliers. This would be dedicated to furthering the interests of organisations-as-buyers rather than suppliers. In naming this nascent sub-field, instead of choosing 'Supplying' behaviour it would of course be possible to use the terms 'Marketing' or 'Selling Behaviour'. However, the terms 'Selling' and 'Marketing' have active, customer satisfaction-seeking connotations that are directly at odds with the phenomenon being studied here with its focus on the satisfaction of suppliers' needs, wants and preferences; hence the choice of 'Supplying Behaviour'. Just as suppliers wishing to obtain the optimum response from customers may draw upon the behavioural insights generated in OBB research, so buyers wishing to obtain the optimum response from suppliers may benefit 
from research into OSB. 


\section{References}

Anderson, E., ( 1985), The salesperson as outside agent or employee: a transaction cost analysis, Marketing Science (pre 1986), Linthicum, Summer, 4, 3, p 234-256

Baily, P., Farmer, D., Jessop, D. \& Jones, D., (2005), Purchasing Principles and Management, Prentice Hall, Harlow

Baker, M., (2000), The Marketing Book, Oxford: Butterworth- Heinemann, Oxford

Benton, W., (2007), Purchasing and Supply Management, McGraw-Hill, Boston USA

Blois, K., (2004), 'Analysing exchanges through the use of value equations', Journal of Business \& Industrial Marketing, 19, 4, pp. 250-257

Brassington, F., \& Pettitt, S., (2006), Principles of Marketing, Harlow: Prentice Hall

Campbell, N. \& Cunningham, M., (1983), 'Customer Analysis for Strategy Development in Industrial Markets', Strategic Management Journal, 4, 4, pp. 369-380

Carr, A. \& Smeltzer, L., (2000), 'An empirical study of the relationships among purchasing skills and strategic purchasing, financial performance, and supplier responsiveness', The Journal of Supply Chain Management, 36, 3, pp. 40-54.

Chopra, S. \& Meindl, P. (2007), Supply Chain Management: Strategy, Planning \& Operation, Pearson, Upper Saddle River USA

Christiansen, P. \& Maltz, A., (2002), Becoming an “Interesting Customer”: Procurement Strategies for Buyers without leverage, International Journal of Logistics: Research and Applications, 5, 2, 
pp. $177-195$

Christopher, M., (2005), Logistics and Supply Chain Management: Creating Value-Adding Networks, FT Prentice-Hall, Harlow UK

Competition Commission, (2000), Supermarkets: A report on the supply of groceries from multiple stores in the United Kingdom, London, HMSO

Cordon, C. \& Vollman, T., (2005), 'Who's the fairest of them all?', CPO Agenda, Autumn, 1, 3, pp. $24-28$

Cordon, C. \& Vollman, T. (2002) The Next Game in Purchasing: Be The Most Attractive Customer To key Suppliers, Perspectives for Managers, No. 86, January, IMD International: Lausanne

De Boer, L. Labro, E. \& Morlacchi, P. (2001) A review of methods supporting supplier selection, European Journal of Purchasing and Supply Management, 7, 2, June, pp. 75-89

Department for Business, Enterprise and Regulatory Reform (DBERR), (2007), Small and Medium-sized Enterprise (SME) Statistics for the UK 2006, http://stats.berr.gov.uk/ed/sme/smestats2006-ukspr.pdf, accessed 4.2.08

Dwyer, F. \& Tanner F., (1999), Business Marketing: Connecting Strategy, Relationships and Learning, New York: McGraw-Hill

Ellegaard, C. \& Ritter, T., (2006a), 'The concept of attraction - its purchasing potential', $4^{\text {th }}$ Annual Supply Chain Management Research Symposium, University of San Diego, April 6thj- $8^{\text {th }}$, pp. $1-10$ 
Ellegaard, C., (2006b), 'Small company purchasing: A research agenda', Journal of Purchasing \& Supply Management, 12, 5, pp. 272-283

Ellegaard, C., Johansen, J. \& Drejer, A., (2003), 'Managing Industrial Buyer-supplier relations - the case for attractiveness', Integrated Manufacturing Systems, 14, 4, pp. 346-356

Ellinor, R., (2008), 'BA joins fight for suppliers', Supply Management, $14^{\text {th }}$ February, p. 7

Ellinor, R., (2007), 'Crowd Pleaser', Supply Management, $13^{\text {th }}$ December, pp. 26-29

Ellis, J., Williams, D. \& Ma, J-H., (2002), ‘Cross-cultural industrial organisational buying behaviour in China and United Kingdom: comparative organisational effectiveness issues and perspectives', Asia in Extenso, pp. 1-12

Essig, M. \& Amann, M., (2005), 'Supplier Valuation Management: Strategies and Concepts for Value Determination and Value Preservation for Suppliers,' Proceedings of the 14th IPSERA Conference, pp. 553-566

Fiocca, R., (1982), 'Account portfolio Analysis for Strategy Development', Industrial Marketing Management, 11, 1, pp. 53-62

Ford, D., Hakansson, H., Lundgren, A., Snehota, I., Turnbull, P., and Wilson, D., (2003), Managing Business Relationships, Chichester: Wiley

Hollensen, S., (2003), Marketing Management: A Relationship Approach, London: Prentice Hall

Holweg, M., (2005), 'An investigation into supplier responsiveness - empirical evidence from the automotive industry', International Journal of Logistics Management, 16, 1, 
pp. 96-119.

Hutt, M. \& Speh, T., (2007), Business Marketing Management: Mason: Thomson

Kanter, J., (2008), "'Customer of choice" crucial, Supply Management, 27 ${ }^{\text {th }}$ March, p.11

Kotler, P., (2003), Marketing Management, New Jersey: Pearson Education International

Krapfel, R., Salmond, D. \& Spekman, R., (1991), 'A strategic approach to managing buyer-seller relationships', European Journal of Marketing, 25, 9, pp. 22-37

Lindgreen, A. \& Wynstra, F., (2005), 'Value in business markets: What do we know? Where are we going?', Industrial Marketing Management, 34, pp. 732-748

Mack, H., (1971), Six painful steps to profitable selling, Sales Management, 107, 8, pp 42-50

Maunu, S., (2003), Supplier Satisfaction: The concept and a measurement system, Unpublished PhD Thesis, Department of Industrial Engineering and Management, University of Oulu, available at: http://herkules.oulu.fi/isbn9514271688/isbn9514271688.pdf, accessed 6.4.07

Monczka, R. Trent, R. \& Handfield, R. (2005), Purchasing and Supply Chain Management, Thomson South-Western, Mason USA

Ramsay, (1994), 'Purchasing Power', European Journal of Purchasing and Supply Management, 1,3, pp. $125-138$

Ramsay, J., (1996), 'Power Measurement', European Journal of Purchasing and Supply, 2, 2/3, pp. $129-143$ 
Ramsay, J., (2005), 'The real meaning of value in trading relationships', International Journal of Operations \& Production Management, 25, 6, pp. 546-565

Reinartz, W. \& Kumar, V., (2003), 'The impact of customer relationship characteristics on profitable lifetime duration', Journal of Marketing, 67, January, pp. 77-99

Roemer, E., (2006), 'The impact of dependence on the assessment of customer lifetime value in buyer-seller relationships', Journal of Marketing Management', 22, pp. 89-109

Rozemeijer, F. and Van Weele, A., (2002), 'Mirror, mirror on the wall, let suppliers guide you towards improvement', DILF Orientering, June, pp. 12-18 (Danish)

Russill, R., (1997), Purchasing Power: Yours suppliers, your profits, London: Prentice Hall Shapiro, B., Rangan, K., Moriarty, R. \& Ross, E., (1987), 'Manage customers for profits (not just for sales)', Harvard Business Review, September-October, pp. 101-108

Sheth, J., (1996), 'Organizational buying behaviour: past performance and future expectations', Journal of Business and Industrial Marketing, 11, 3, pp. 7-24

Tanner, J., (1990), 'Predicting organizational buying behaviour', Journal of Business and Industrial Marketing, 5, 2, pp. 75-81

Ulaga, W. \& Eggert, A., (2006), 'Value-based differentiation in business relationships: gaining and sustaining key supplier status'. Journal of Marketing, 70, pp. 119-136.

Ulaga, W. \& Eggert, A., (2005), 'Relationship value in business markets: the construct and its dimensions', Journal of Business-to-Business Marketing, 12, 1, pp. 73-99 
Van Weele, A., (2005), Purchasing \& Supply Chain Management: Analysis, Strategy, Planning and Practice, Thomson, London

Venkatesan, R. \& Kumar, V., (2004), “A Customer Lifetime Value Framework for Customer Selection and Resource Allocation Strategy," Journal of Marketing, 68, October, pp. 106-125.

Walter, A., Müller, T., Helfert, G. \& Ritter, T., (2003), 'Functions of industrial supplier relationships and their impact on relationship quality', Industrial Marketing Management, 32, pp. 159-169

Walter, A., Ritter, T. \& Gemünden, D., (2001), 'Value-creation in buyer-seller relationships: theoretical considerations and empirical results from a supplier's perspective', Industrial Marketing Management, 30, 5, pp. 365-377

Webster, F., (1991), Industrial Marketing Strategy, New York: John Wiley \& Sons

Webster, F. \& Wind, Y., (1996), 'A general model for understanding organizational buying behaviour', Marketing Management, 4, 4, pp. 52-58 Wilson, E., (1996), 'Theory transitions in organisational buying behaviour research', Journal of Business and Industrial Marketing, 11, 6, pp. 7-21 Yorke, D. \& Wallace, K., (1986), 'A Customer Selection Strategy for Business Markets', Journal of Marketing Management, 2, 2, pp. 181-191 


\section{Table 1 Literature-based Sources of Supplier Value}

\begin{tabular}{|c|c|}
\hline Source of supplier value & Reference cited in this paper \\
\hline \multicolumn{2}{|l|}{ Finance: } \\
\hline Overall Profit: & $\begin{array}{l}\text { Russil, 1997, p. 108; Walter et al, 2001, p. 367; Maunu, 2003, p.75; } \\
\text { Kotler, 2003, p. } 38 \text { \& p. 56; Baker, 2000, pp. 473-475; Hollensen, } \\
\text { 2003, pp. 16-17; Roemer, 2006; Venkatesan \& Kumar, 2004; } \\
\text { Reinartz \& Kumar, 2003; Dwyer \& Tanner, 1999; Campbell \& } \\
\text { Cunningham, 1983, p. } 372 \text { [This is merely a small sample. } \\
\text { References to this particular SOSV are ubiquitous] }\end{array}$ \\
\hline Revenue Elements & Ramsay, 1996, p. 133 \\
\hline Cost Elements: & $\begin{array}{l}\text { Fiocca, 1982, p. 55; Shapiro et al, 1987, p. 102; Russil, 1997, p. } \\
\text { 108; }\end{array}$ \\
\hline Sales Volume: & $\begin{array}{l}\text { Ramsay, 1994, p. 130; Walter et al, 2001, p. } 367 \text {; Ellegaard et al, } \\
\text { 2003, p. 347; Fiocca, 1982, p. 54; Campbell \& Cunningham, 1983, } \\
\text { p. 372; }\end{array}$ \\
\hline Sales Impact (Sales/Total Sales): & Ramsay, 1994, p. 130; Ramsay, 1996, p. 132; Russil, 1997, p. 108 \\
\hline Sales Potential: & Fiocca, 1982, p. 55; Campbell \& Cunningham, 1983, p. 372 \\
\hline Payment Format: & Ramsay, 1994, p. 130; Ramsay, 2005, p. 556 \\
\hline Windfalls: & Ramsay, 2005, p. 556 \\
\hline Lack of Negotiating Pressure: & Cordon \& Vollmann, 2005, p. 26; Shapiro et al, 1987, p. 105 \\
\hline \multicolumn{2}{|l|}{ Efficiency } \\
\hline Supplier Learning Opportunities: & Cordon \& Vollman, 2002, p. 2; Ellegaard et al, 2003, p. 347 \\
\hline Low Modification Rate: & Cordon \& Vollmann, 2005, p. 26 \\
\hline Appropriately Trained Staff: & Christiansen \& Maltz, 2002, p. 181 \\
\hline \multicolumn{2}{|c|}{ Overall Trading Relations and Communication } \\
\hline $\begin{array}{l}\text { Good Inter-organisational Staff } \\
\text { Relations: }\end{array}$ & Ford et al, 2003, p. 160 \\
\hline Personal Preferences: & Russill, 1997, p. 120; Ramsay, 2005, p. 557 \\
\hline Personal Motivation: & Ramsay, 2005, p. 557 \\
\hline Personal Meetings: & Rozemeijer \& Van Weele 2002, p. 16 \\
\hline
\end{tabular}




\begin{tabular}{|c|c|}
\hline Contact Stability: & Cordon \& Vollmann, 2005, p. 26 \\
\hline Long-term Interactions: & $\begin{array}{l}\text { Christiansen \& Maltz, 2002, p. 184; Fiocca, 1982, p. 54; Campbell } \\
\& \text { Cunningham, 1983, p. 369; Ellegaard et al, 2003, p. } 347\end{array}$ \\
\hline Roles \& Responsibilities: & Rozemeijer \& Van Weele 2002, p. 16; Maunu, 2003, p. 96; \\
\hline Performance Feedback: & Rozemeijer \& Van Weele 2002, p. 16; Maunu, 2003, p. 96 \\
\hline Joint Teams: & Rozemeijer \& Van Weele 2002, p. 16 \\
\hline Customer Attentiveness: & Christiansen \& Maltz, 2002, p.184; Ramsay 2005, p. 556 \\
\hline Receptiveness to Supplier Ideas: & Cordon \& Vollmann, 2005, p. 27 \\
\hline \multicolumn{2}{|l|}{ Ethical behaviour } \\
\hline Fairness: & Cordon \& Vollmann, 2005, p. 27; Essig \& Amman, 2005, p. 559 \\
\hline Trustworthiness: & $\begin{array}{l}\text { Maunu, } 2003 \text {, p. } 75 \text {; Ramsay, 2005, p. 557; Cordon \& Vollmann, } \\
\text { 2005, p. } 27\end{array}$ \\
\hline \multicolumn{2}{|l|}{ Risk and Uncertainty } \\
\hline Risk Sharing: & Christiansen \& Maltz, 2002, p. 181; Maunu, 2003, p. 95 \\
\hline Revenue Insurance: & Walter et al, 2001, p. 368; Christiansen \& Maltz, 2002, p. 187 \\
\hline Demand stability & $\begin{array}{l}\text { Russil, 1997, p. 108; Rozemeijer \& Van Weele 2002, p. 16; Maunu, } \\
\text { 2003, p. 75; Ramsay 2005, p. } 556\end{array}$ \\
\hline Forecast Reliability: & Rozemeijer \& Van Weele 2002, p. 16 \\
\hline Early R\&D Involvement: & $\begin{array}{l}\text { Rozemeijer \& Van Weele 2002, p. 16; Maunu, 2003, p. 93; Essig \& } \\
\text { Amman, 2005, p. } 562\end{array}$ \\
\hline Financial Probity: & $\begin{array}{l}\text { Russil, 1997, p. 108; Ramsay, 2005, p. 556; Cordon \& Vollmann, } \\
\text { 2005, p. } 26\end{array}$ \\
\hline Supplier Independence/Power: & $\begin{array}{l}\text { Ramsay, 1994, p. 129; Shapiro et al, 1987, p. 104; Krapfel et al, } \\
\text { 1991, p. } 25\end{array}$ \\
\hline Buyer Dependence/Power: & $\begin{array}{l}\text { Ramsay, 1994, p. 137; Fiocca, 1982, p. 55; Campbell \& } \\
\text { Cunningham, 1983, p. } 376\end{array}$ \\
\hline Interest Commonality: & Krapfel et al, 1991, p. 26 \\
\hline Diversification Facilitation: & Fiocca, 1982, p. 55 \\
\hline
\end{tabular}




\begin{tabular}{|c|c|}
\hline \multicolumn{2}{|l|}{ Technology } \\
\hline Customer-led innovation: & $\begin{array}{l}\text { Walter et al, 2001, p. 368; Christiansen \& Maltz, 2002, p. 180; } \\
\text { Fiocca, 1982, p. } 55\end{array}$ \\
\hline Supplier-led Innovation Support: & Christiansen \& Maltz, 2002, p. 180 \\
\hline \multicolumn{2}{|l|}{ Market Linkages } \\
\hline Market Access: & $\begin{array}{l}\text { Walter et al, 2001, p. 368; Christiansen \& Maltz, 2002, p. 181; } \\
\text { Fiocca, 1982, p. } 55\end{array}$ \\
\hline Institutional Access: & Walter et al, 2001, p. 368 \\
\hline Market Information: & Walter et al 2001, p. 368 \\
\hline Competitor Sales Support: & Fiocca, 1982, p. 55 \\
\hline \multicolumn{2}{|l|}{ Corporate Image } \\
\hline Reputation: & $\begin{array}{l}\text { Russil, 1997, p. 108; Fiocca, 1982, p. 54; Campbell \& Cunningham, } \\
\text { 1983, p. 374; ; Ramsay, 2005, p. } 556\end{array}$ \\
\hline
\end{tabular}


Table 2

\begin{tabular}{|c|c|}
\hline $\begin{array}{l}\text { Source of } \\
\text { Supplier value }\end{array}$ & Sample Response \\
\hline Overall Profit & $\begin{array}{l}\text { "Whereas customers } 1 \text { and } 2 \text { a real, paranoid about the selling price. A lot are } \\
\text { asking us to make up the difference in the margin. We have to be strong. Just now } \\
\text { I am trying to get customer } 2 \text { to get the price up and stop the downward } \\
\text { pressure..." }\end{array}$ \\
\hline Revenue Elements & $\begin{array}{l}\text { "Need to get on to (customer 6's) buying list. This is difficult and they want huge } \\
\text { discounts. I won't go to (customer 1) as they want a selling price that is too low." }\end{array}$ \\
\hline Cost Elements & $\begin{array}{l}\text { "When the market price for raw materials fluctuates, a fall,(Customer 4) expect } \\
\text { lower prices, but when there is an increase they are not interested." }\end{array}$ \\
\hline Sales Potential & $\begin{array}{l}\text { "If you can develop a winning product the distribution opportunities major } \\
\text { retailers offer are very large." }\end{array}$ \\
\hline Payment Format & "The admin. costs are huge, and the credit terms quite long." \\
\hline $\begin{array}{l}\text { Supplier Learning } \\
\text { Opportunities }\end{array}$ & $\begin{array}{l}\text { "The retailers... are always on the ball in terms of what is happening legislation- } \\
\text { wise. So doing all the own label products helps us keep up with the regulations." }\end{array}$ \\
\hline $\begin{array}{l}\text { Appropriately Trained } \\
\text { Staff }\end{array}$ & "Generally the buyers are more knowledgeable." \\
\hline $\begin{array}{l}\text { Good Inter- } \\
\text { organisational Staff } \\
\text { Relations }\end{array}$ & "The buyers (at customer 2) treat the supplier with more respect." \\
\hline Personal Preferences & "(Customer 1) at this time are easy and pleasant to work with. \\
\hline
\end{tabular}




\begin{tabular}{|c|c|}
\hline Personal Meetings & $\begin{array}{l}\text { "The biggest problem is trying to meet people It is very difficult to get decisions } \\
\text { made if we can't meet people. You get a lot more out of it when the meeting is } \\
\text { face-to-face." }\end{array}$ \\
\hline Contact Stability & $\begin{array}{l}\text { "The turnover of buyers is very high with our customers. It can be frustrating } \\
\text { when building the relationship up." }\end{array}$ \\
\hline Long-term Interactions & $\begin{array}{l}\text { "We have had a very good run with customer 2. But buyers change frequently so } \\
\text { this does not feel lie a long term relationship." }\end{array}$ \\
\hline Roles \& Responsibilities & $\begin{array}{l}\text { "(Customer 1) at this time are easy and pleasant to work with. Parameters are } \\
\text { set out and you know where you stand." }\end{array}$ \\
\hline Customer Attentiveness & $\begin{array}{l}\text { "There are new regulations coming through...regarding allergies...the retailers } \\
\text { will be on it right away. But if we have two years worth of packaging they will say } \\
\text { that we shouldn't have two years worth." }\end{array}$ \\
\hline $\begin{array}{l}\text { Receptiveness to } \\
\text { Supplier Ideas }\end{array}$ & "Buyers change. Sometimes they don't listen to you." \\
\hline Trustworthiness & $\begin{array}{l}\text { "I think the multiples can be 'forked tongued' and twisted in terms of supporting } \\
\text { dairy farmers. The multiple gets } 30 \% \text { margin on the milk." }\end{array}$ \\
\hline Risk Sharing & $\begin{array}{l}\text { "The supplier bears all the risk with regard to inventory holding. This is OK for } \\
\text { [supplier 5] because the parent company has considerable resources. However it } \\
\text { is more difficult for the really small supplier." }\end{array}$ \\
\hline Forecast Reliability & $\begin{array}{l}\text { "There is little or no responsibility on the part of the buyer for the decisions they } \\
\text { have made. The expectation is that we will absorb costs based on particular } \\
\text { mistakes e.g. on forecasting. Inaccurate demand/forecast figures by customers." }\end{array}$ \\
\hline Financial Probity & $\begin{array}{l}\text { "Sometimes they don't pay on time, when we started to work with them we did not } \\
\text { get paid for } 4 \text { months, This has a big impact on us." }\end{array}$ \\
\hline $\begin{array}{l}\text { Supplier } \\
\text { Independence/Power }\end{array}$ & $\begin{array}{l}\text { "I would be wary of developing business with (a named customer) because of the } \\
\text { legions of stories of the n helping a supplier get to a size that are totally } \\
\text { dependent on (a named customer)." }\end{array}$ \\
\hline
\end{tabular}




\begin{tabular}{|l|l|}
$\begin{array}{l}\text { Buyer } \\
\text { Dependence/Power }\end{array}$ & $\begin{array}{l}\text { "In most cases the retailers have all the bargaining power although we are } \\
\text { working to try and offset this a little by signing exclusive agreements." }\end{array}$ \\
\hline $\begin{array}{l}\text { Customer-led } \\
\text { Innovation }\end{array}$ & $\begin{array}{l}\text { "The biggest benefit we have had in developing our business is in the professional } \\
\text { standards they set which hopefully results in [Supplier 1] being professionally } \\
\text { run." }\end{array}$ \\
\hline Support & $\begin{array}{l}\text { "I would like to see a bit more flair amongst the supermarkets. Unfortunately in } \\
\text { the UK it is all about lower prices. We could do a lot with packaging; new lines; } \\
\text { more convenience." }\end{array}$ \\
\hline Market Information & $\begin{array}{l}\text { "With the supermarkets we have a captive audience and can do tastings and } \\
\text { Promotions. We can increase the number of cases considerably. }\end{array}$ \\
\hline Reputation & $\begin{array}{l}\text { "They (customer 2) are leaders in environmental issues. They seem to have a } \\
\text { moral obligation to consider the planet. I think we are sleepwalking to a massive } \\
\text { environmental problem with the planet. Business showing the government the } \\
\text { way. (Customer 2) are there first." }\end{array}$ \\
\hline
\end{tabular}


Table 3

Source of Supplier Value

Finance

Overall Profit

Revenue elements

Cost elements

Sales Volume

Sales Impact

Sales Potential

Payment Format

Speed of Payment

Windfalls

Lack of Negotiating Pressure

Efficiency

Supplier Learning opportunities

Low Modification rate

Appropriately Trained Staff

Administrative Flexibility

Overall Trading Relations \& Communications

Good Inter-organisational Staff Relations

Personal Preferences

Personal Motivation

Personal Meetings

Contact Stability

Long-term Interactions

Roles \& Reponsibilities

Performance Feedback

Joint Teams

Customer Attentiveness

Receptiveness to Supplier Ideas

Free \& Timely Information Flow

Staff Access

Ethical Behaviour

Fairness

Trustworthiness

Honesty

Absence of Corruption

Risk and Uncertainty

Risk Sharing

Revenue Insurance
Respondent Firm

\section{$\begin{array}{lllllllllll}\text { Frequency } & 1 & 2 & 3 & 4 & 5 & 6 & 7 & 8 & 9 & 10\end{array}$}

5

6

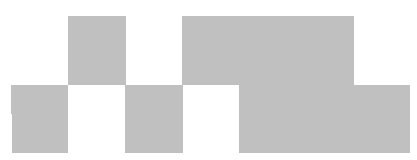

2

1

1

4

1

1

4

1

1

5

3

5

5

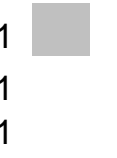

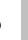

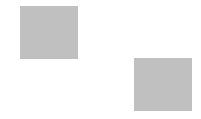

.
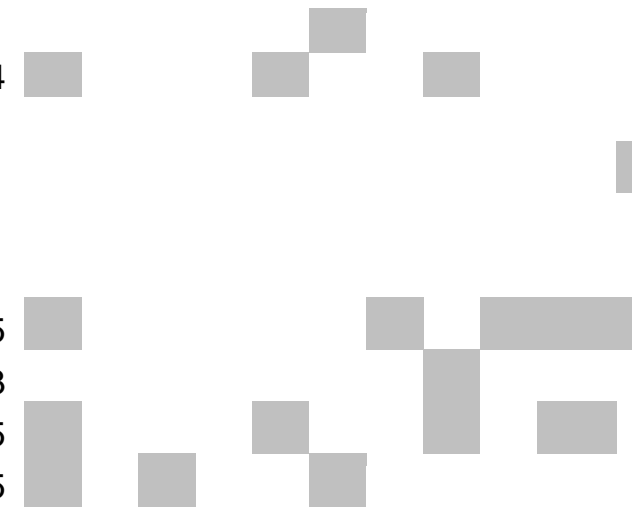

4

1

2

3 
Demand Stability

Forecast Reliability

Early R\&D Involvement

Financial Probity

Supplier Independence/Power

Buyer Dependence/Power

Interest Commonality

Diversification Facilitation

Price Stability

Technology

Customer-led Innnovation

Supplier-led Innovation Support

Trading Linkages

Market Access

Institutional access

Market Information

Competitior Sales Support

Corporate Image

Reputation
2

1

6

2

2

2
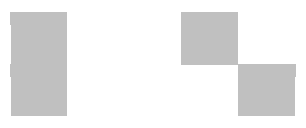

1 